\title{
DELINEATION AND CLASSIFICATION OF KARST DEPRESSIONS USING LIDAR: FORT HOOD MILITARY INSTALLATION, TEXAS
}

\author{
Melinda G. Shaw Faulkner, Kevin W. Stafford, Aaron W. Bryant \\ Department of Geology, Stephen F. Austin State University, P.O. Box 13011, SFA Station, Nacogdoches, TX, 75962-3011, \\ mgshaw@sfasu.edu
}

\begin{abstract}
The Fort Hood Military Installation is a karst landscape characterized by Cretaceous-age limestone plateaus and canyons in Bell and Coryell Counties, Texas. The area is located in the Lampasas Cut Plain region of the Edwards Plateau and is stratigraphically defined by exposures of the Fredericksburg Group. Spatial interpolation of $105 \mathrm{~km}^{2}$ of the Fort Hood Military Installation provided depression data that were delineated and classified using geoanalytical methods. Most of the karst features within the study area are predominantly surficial expressions of collapse features, creating windows into karst conduits with surficial exposures of epikarst spatially limited.
\end{abstract}

The increasing capabilities of GIS (Geographic Information Systems) and accuracy of geographically referenced data has provided the basis for more detailed terrain analysis and modeling. Research on terrain-related surface features is highly dependent on terrain data collection and the generation of digital models. Traditional methods such as field surveying can yield accurate results; however, they are limited by time and physical constraints. Within the study area, dense vegetation and military land use preclude extensive traditional karst survey inventories. Airborne Light Detection and Ranging (LiDAR) provides an alternative for high-density and high-accuracy three-dimensional terrain point data collection. The availability of high density data makes it possible to represent terrain in great detail; however, high density data significantly increases data volume, which can impose challenges with respect to data storage, processing, and manipulation. Although LiDAR analysis can be a powerful tool, filter mechanisms must be employed to remove major natural and anthropogenic terrain modifications resulting from military use, road building and maintenance, and the natural influence of water bodies throughout the study area.

\section{Introduction}

The Fort Hood Military Installation is located within the Lampasas Cut Plain region of the Edwards Plateau in Bell and Coryell counties (Figure 1). The plateau topography is mostly flat over broad drainage divides and becomes rolling in areas proximal to streams, exposing Cretaceous carbonates from the Fredericksburg and Washita Groups (Figure 2). The climate of the Edwards Plateau is sub-humid and becomes increasingly arid to the west and cooler to the north. Courtesy of the Gulf Stream, prevailing winds are generally from the south and the general decrease in moisture content of Gulf air as it flows northwestward across the Plateau is the controlling factor responsible for this difference in moisture regime (Bradley and Malstaff 2004). Soil development is minimal on the upper plateau over the

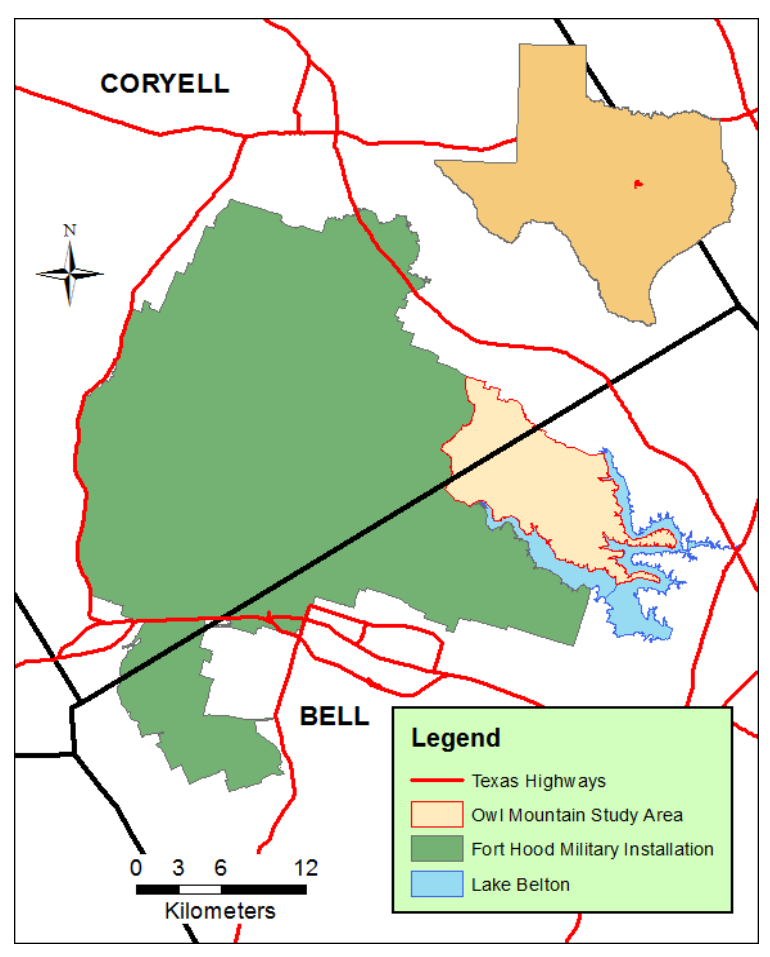

Figure 1. Owl Mountain study area within the Fort Hood Military Installation. 


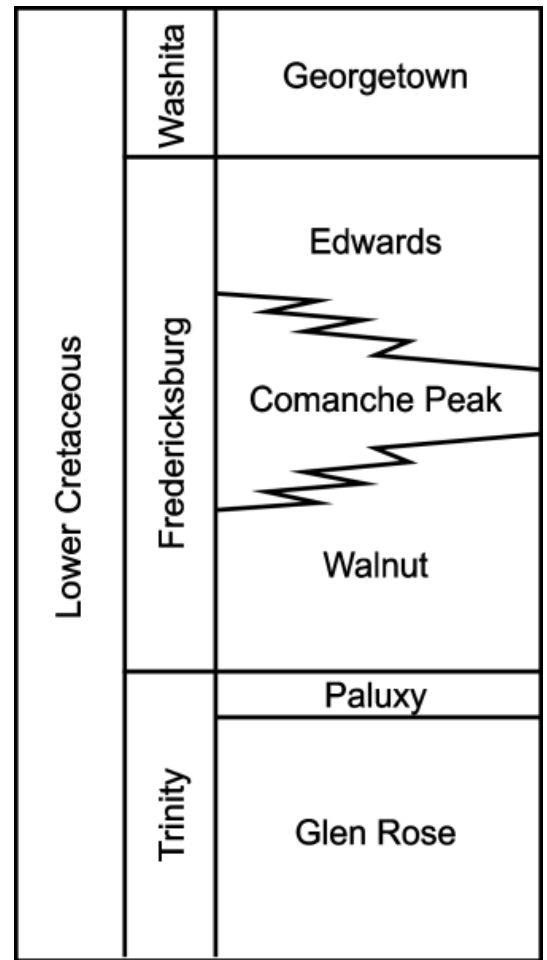

Figure 2. Stratigraphic column of the Trinity, Fredericksburg, and Washita Groups of the Lower Cretaceous.

Edwards Group; thicker soils accumulate at the base over the Comanche Peak and Walnut Clay units that dominate the valleys.

The study area is the eastern portion of the Fort Hood Military Installation known as the Owl Mountain province. The area is approximately $105 \mathrm{~km}^{2}$ and is bounded by Owl Creek to the north, Lake Belton to the east, Cowhouse Creek to the south and the live fire impact zone to the west (Figure 1). The area has been modified for military training purposes and grazing, and the present vegetation and geomorphology are a reflection of the multi-purpose land use and water availability. This area is home to several endangered species such as the Setophaga chrysoparia, Vireo atricapilla, a nesting songbird; Acer grandidentatum, a rare maple relict from the Pleistocene ice age found in slot canyons within the study area; and Croton alabamensis var. texensis, a rare shrub that has been documented in only a few locations in the United States (Picinich 2011).

\section{Geologic Setting}

The Owl Mountain province is a karst landscape characterized by local Cretaceous-age limestone plateaus and canyons with rock outcrops, cliffs, sinkholes, caves, springs, and rock shelters. Strata from the Trinity (Glen Rose), Fredericksburg (Edwards), and Washita (Georgetown) Groups with patches of limestone, dolomite, chert and marl alternately crop out at the surface and as scarps along incised stream valleys in the area. These exposures have been described as mounds or shoals that developed in shallow water, high energy environments; possibly as part of the restrictive structure that enabled the deposition of the evaporitic material in the Kirschberg lagoon to the southwest (Fisher and Rodda 1969). The trend of these formations, formed across the axis of the Belton High (Figure 3), follow the model presented for Moffatt Mound (Amsbury et al. 1984; Brown 1975) (Figure 4). The Moffatt Mound area consists of thicker, more well-defined outcrops of Edwards Group strata that are lithologically distinct from the main Edwards reef trend. The eastern section of the Fort Hood Military Installation, including the Owl Mountain province, is thought to be a remnant of one of these isolated structures (Amsbury et al. 1984).

Early geologic mapping by Barnes (1970) shows the undivided Edwards Group conformably overlying the Comanche Peak Limestone. Most of the units are relatively unaltered and generally flat-lying or slightly

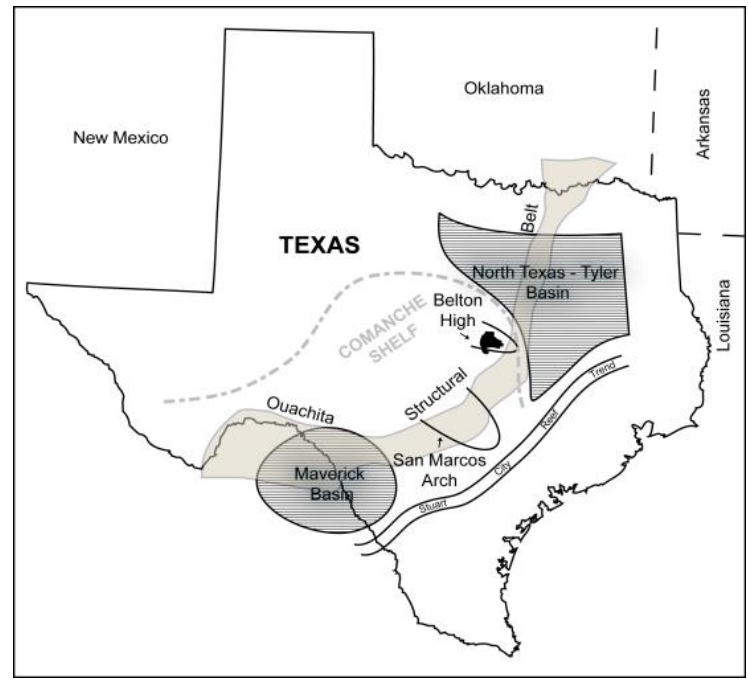

Figure 3. Location map showing the regional features influencing the depositional environment for the Fredericksburg Group on the Comanche Shelf behind the Stuart City Reef Trend. The Belton High, a smaller, structural high similar to the San Marcos Arch, provided the depositional environment for the mounds and shoals behind the main reef structure. 


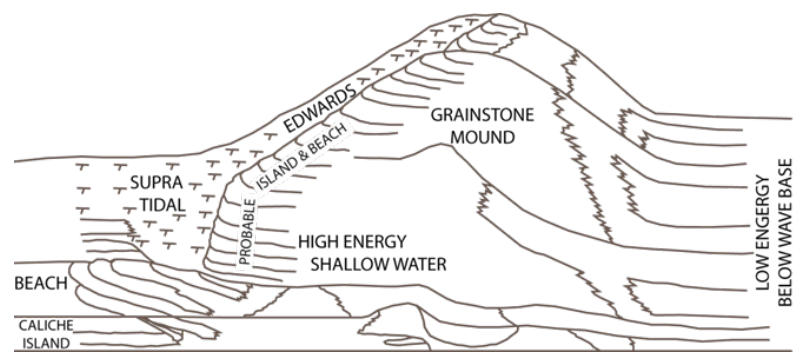

Figure 4. Conceptual depositional model of the carbonate Moffat Mound structure. (Bryant 2012, adopted from Amsbury et al. 1984).

dipping to the east, although the top surface of the Edwards does show some undulation. Deposition of these units began approximately 110 mya on the Comanche Shelf, which was constructed on the tectonically positive Llano and Devils River uplifts in Texas behind the Stuart City Reef complex (Nelson 1973)(Figure 3). The Comanche Shelf was bounded on the east and south by a relatively deep-water oceanic basin, the ancestral Gulf of Mexico, and on the north and west by an extensive shallow-water open marine basin, the North Texas-Tyler basin (Fisher and Rodda 1969).

Within the study area, the Glen Rose and Paluxy Sand formations provide the substrate for the overlying strata (Figure 2). The upper section of the Glen Rose lies underneath the exposed units and is composed of limestone, dolostone and marl that were deposited in a variety of environments such as marine, tidal-flat, reef and hyper-saline settings (Barnes 1970). The Paluxy Sand is a friable, fine- to very fine-grained, quartz sandstone with partial calcite cement that overlies the Glen Rose Formation. Although it may be present in the subsurface, no outcrops have been documented by current studies in the study area.

The Walnut Clay overlies the Glen Rose and Paluxy deposits and forms the lowland floor of the study area. Walnut deposits represent transgressive facies and are subdivided into six members; in the study area the Keys Valley Marl is the prominent member. This unit lies in gradational contact with the overlying Comanche Peak Limestone in the subsurface and is exposed at lower elevations (Adkins \& Arick 1930). Specific facies within the Walnut Formation include mudstones, wackestones and packstones, containing fossil assemblages of pelecypods, echinoderms and gastropods. In the study area, well-cemented fossil beds of Texigryphaea can be found near the current base level of stream channels and along the shores of Lake Belton.
The Comanche Peak Formation is a nodular limestone and marl sequence with a maximum thickness in Bell and Coryell counties of approximately $21 \mathrm{~m}$. The Comanche Peak has transitional contacts with the underlying Walnut Clay and the overlying Edwards Group (Senger et al.1990). Most of the Comanche Peak is not distinctly bedded, and their transitional contact can be readily distinguished in outcrop from the overlying Edwards. Fossil content and permeabilities within this unit are considerably less than the overlying Edwards Group.

The Edwards Group is a series of massive to thin-bedded limestones, dolostones and marls containing mudstone, wackestone, packstone and grainstone facies with chert nodules and rudistid biostromes. These facies form the cap rock of the study area and varies from rudistid rich limestone to vuggy, porous outcrops of peloidal and oolitic wackestone to packstone. The Edwards Group can be informally divided into four members, and although these informal designations have been described and named, most mapping and descriptions of the northern outcrops of the Edwards Group are not differentiated. Epikarst development is spatially limited with some spongework epikarst developing in areas with a thin veneer of soil.

The Georgetown Formation, a unit within the Washita Group, consists of fossiliferous limestone, argillaceous limestone and minor marl that have wackestone, packstone and grainstone facies. Pelecypods are diagnostic features of the Georgetown Formation, as well as vuggy porosity present in some of the facies. Although these rocks are included as part of the Northern Edwards Aquifer, none are mapped separately in the study area.

In the Owl Mountain province, the Walnut Clay, Comanche Peak and Edwards formations crop out at the surface (Figure 5). The lower valleys along creeks and rivers are covered by thicker soil and vegetative cover developing over the Walnut and lower portion of the Comanche Peak. Comanche Peak outcrops are exposed along the base of the plateaus, interfingering with exposures of the Edwards Group. The recharge zone of the uplands stands alone as a positive topographic feature directly coupled to the atmosphere. Precipitation is either directed into short stream segments and drainage basins or directly into the subsurface through joints, fractures, vugs, sinkholes and smaller conduits. This water will 


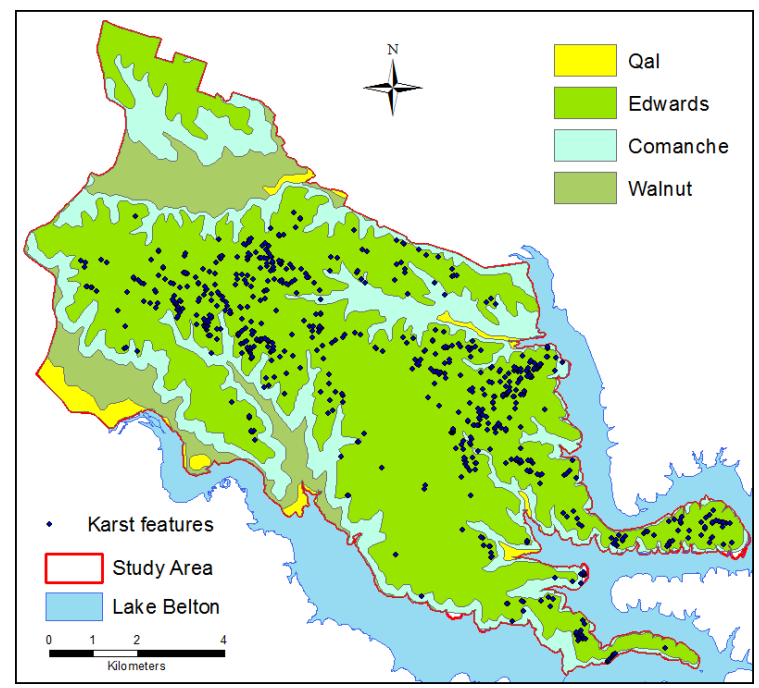

Figure 5. Geologic map of the study area with mapped karst features including caves, shelter caves, springs, sinks, and seeps identified. Karst features were mapped by Reddell et al. (2011) and are part of the ongoing research at Fort Hood.

travel vertically or sub-vertically until it reaches a lower permeability unit; where it will then travel laterally to discharge as one of the numerous springs and seeps on the outer edges of the uplands.

\section{Karst Development}

The level of karst development within the study area is controlled primarily by lithology; where the Edwards Group is exposed to meteoric influences, the more advanced dissolution and karst development (Figure 5). Many of the sub-surface karst features are fracture controlled, displaying both local and regional trends (McCann 2012), with karst feature development controlled by lithologic and permeability boundaries within and between the contacts of the Walnut Clay, Comanche Peak and Edwards units.

Regional uplift of the Edwards Group as a result of the Laramide orogeny resulted in the exposure and partial erosion of these units, increasing secondary porosity and tilting the strata to the southeast (Elliott and Veni 1994). During the Miocene, faulting and subsequent uplift along the Balcones initiated the development of drainage systems and as the stream segments incised exposed rock, the intersection of fracture conduits with stream base level helped widen cavities and develop spring discharge outlets. Some karst development is controlled by bedding planes with springs, seeps, and rock shelters developing along the interface of lithological contacts between the Walnut Clay, Comanche Peak and Edwards units. To date, surface mapping by Reddell et al. (2011) across the entire military installation have identified over 300 caves, 80 springs, 667 sinks and 491 shelter caves have been delineated (Figure 5).

Most of the karst features identified within Fort Hood are coupled to the surface and exhibit solutional widening and overprinting by meteoric waters. Sinkholes and cave entrances are often small and associated drainage basins are spatially limited, generally covering less than one hundred square meters in area. In the study area, many sinkholes and cave entrances appear to have formed as upward stoping collapse structures and/or features that have been breached by surficial denudation (Bryant 2012). Cave development is commonly associated with high-angle scarps truncated by abrupt eroded edges of the plateaus in the eastern portion.

\section{GIS Analyses}

The increasing capabilities of GIS (Geographic Information Systems) and accuracy of geographically referenced data has provided the basis for more detailed terrain analyses and modeling (Liu, 2008). Through spatial interpolation of available LiDAR data, depressions associated with karsting can be delineated and classified over terrains using geoanalytical methods. Research on terrain-related surface features is highly dependent on terrain data collection and the generation of digital models. Traditional methods such as field surveying and photogrammetry can yield accurate results; however, they are limited by time and physical constraints. Airborne Light Detection and Ranging (LiDAR) provides an alternative for high-density and high-accuracy three-dimensional terrain point data collection (Liu, 2008). The availability of high density data makes it possible to represent terrain in great detail; however, high-density data significantly increases data volume, which can impose challenges with respect to data storage, processing, and manipulation.

\section{LiDAR}

The LiDAR data used for this study were captured in March of 2009 by Optimal Geomatics (Optimal Geomatics, 2009). The raw data collected from the LiDAR surveys were processed using the software package DASHMap produced by Optech, Inc. (Optimal Geomatics, 2009). DASHMap generated a set of data points for three laser returns, the tree canopy (first return), lower vegetation and 
brush (second return), and bare earth (third return) in an LAS file by using both the GPS and inertial navigation system (INS) roll, pitch, and heading information recorded by the planes POS (Position Orientation System). The LAS files were converted and divided into multipoint shapefiles and stored in a geodatabase for simplicity. The database containing the LiDAR survey data was acquired from the Fort Hood Natural Resources Division and the bare earth LAS files were used to build the initial Digital Terrain Model (DTM) and Digital Elevation Model (DEM) used in this study.

\section{DTM and DEM}

The high density and accuracy of collected elevation points through the airborne LiDAR survey provide the basis for creating a geostatistical model that can then be further analyzed. In order to work within system memory limitations, a Digital Terrain Model (DTM) was built to simplify the management and manipulation of this large dataset (Esri, 2012). In order to perform detailed spatial analyses and utilize the numerous tools available through ArcGIS's Spatial Analyst, the model was converted into a raster format so that cell-by-cell calculations could be made.

A $1 \mathrm{~m}$ resolution DEM was found to be the best model to adequately resolve karst features in the study area without introducing a significant amount of error; the accuracy of the DEM was derived in accordance with the ASPRS Guidelines for Vertical Accuracy Reporting for LiDAR Data (Flood, 2004). The expected horizontal accuracy is $1 / 2000$ th of the flight height, which in this LiDAR survey was $2200 \mathrm{~m}$ above ground level, resulting in a horizontal accuracy of less than $1.1 \mathrm{~m}$. The vertical accuracy of the DEM was found by calculating the root mean square error (RMSE) between validation points of known elevation and the interpolated elevations from the $1 \mathrm{~m}$ DEM. The RMSE of the $1 \mathrm{~m}$ DEM for the study area is $14.04 \mathrm{~cm}$; therefore, the vertical accuracy of interpolated points is less than $27.52 \mathrm{~cm}$.

\section{Depression Identification}

The study area has known karst development and by performing spatial analyses on the high resolution $1 \mathrm{~m}$ DEM, sinkholes or depression features could be identified. To identify closed depressions within the study area, the flow accumulation tool was used to create a raster of accumulated flow for each cell in the DEM. Once the depressions were identified, the fill tool was used to create a filled DEM raster without closed depressions. The original DEM was subtracted from the filled DEM to identify only the closed depression features (Stafford et al., 2002). Depression features were delineated so that their spatial attributes could be measured and classified for further analyses. The boundaries for the depression features were delineated in a five-step process: 1) Convert depression raster to polygons; 2) Buffer polygons to incorporate immediately surrounding area as a depression; 3) Dissolve any overlapping boundaries; 4) Smooth the polygons to remove hard cell boundaries; and 5) Simplify the polygons to remove any extraneous bends. A single polygon represents one depression object; the depression delineation process identified a total of 9,175 depression objects in the study area. Depressions were classified using properties that relate to whether the feature is a naturally occurring karst feature; depressions which intersected or overlapped with natural and anthropogenic terrain modifications were removed progressively from the total list of delineated depressions.

\section{Depression Classification}

The depression identification process identified all depression features in the DEM, which means that depressions associated with river channels, roadways, and other man-made features were also identified (Liu and Wang 2008). In order to identify the depressions associated with karsting, the delineated depressions were filtered and classified by their spatial attributes to remove depressions as a result of natural and anthropogenic activities, and to identify any inherent spatial relationships that may exist.

Depressions were removed or classified by determining their spatial relationship to known anthropogenic and natural influences. Lakes or large bodies of water, roads, and stream locations were first used as classification determinants. Lake Belton, Cowhouse Creek, and Owl Creek, as well as smaller lakes and ponds, were delineated from aerial imagery and any depressions that were within $20 \mathrm{~m}$ of these water bodies were classified as being influenced by those water features (Wang and Liu 2008). Stream segments were delineated for the study area through the creation and classification of a flow accumulation raster (Figure 6). The cells with the highest flow accumulation, greater than $100,000 \mathrm{~m}^{2}$, were isolated and delineated as being a stream feature. Any depressions that were within five meters of a stream segment were classified as being influenced by a stream or river. 


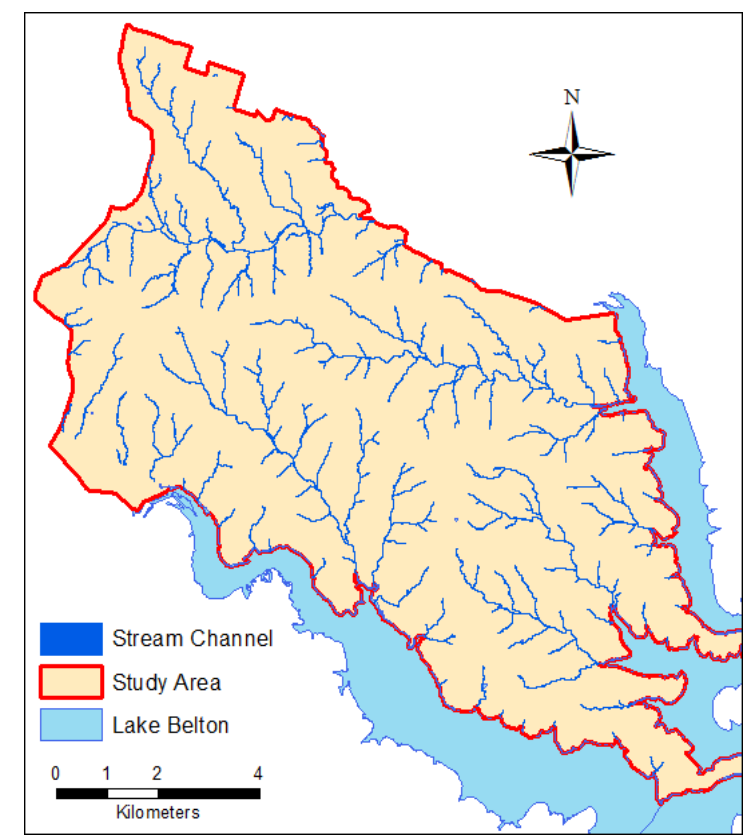

Figure 6. Stream segments were delineated for the study area through the creation and classification of a flow accumulation raster. The cells with the highest flow accumulation, greater than $100,000 \mathrm{~m}^{2}$, were isolated and delineated as being a stream feature and all depressions within $5 \mathrm{~m}$ of the stream segments were removed from the depression database.

The study area contains roads of all types and sizes from the long history of military use, so the major roads were digitized in a dataset (Figure 7). Major roads include large paved roads, tank roads, and pipelines that transect the study area. Any depressions that lie within $20 \mathrm{~m}$ of a major road centerline were classified as being influenced by this feature. Depressions were also classified based on their underlying geology. The Edwards and Comanche Peak formations are the only geological units in the study area known to support karst development therefore depressions occurring outside of those formations are likely to be artificial. Depressions that were located within the Walnut or alluvial deposits were identified and removed from the dataset.

The depth or range of elevation values that exist within a depression were also used as a classification determinant. Because the vertical accuracy of the interpolated surface was found to be within $0.275 \mathrm{~m}$, depressions that were less deep than the accuracy level were classified as potentially artificial because those features cannot accurately be resolved. The depression in Figure 8 is a typical karst feature within the study area; this depression would have been within the limits of the LiDAR resolution, however depending upon where the points were taken, could have been missed by the survey.

Finally, depressions were classified based on vegetation cover type. Depressions that occurred within the bare earth and disturbed herbaceous cover types were removed from the database. These areas are heavily altered by training exercises and military maneuvers and the resulting depressions would be artificially derived (Table 1).

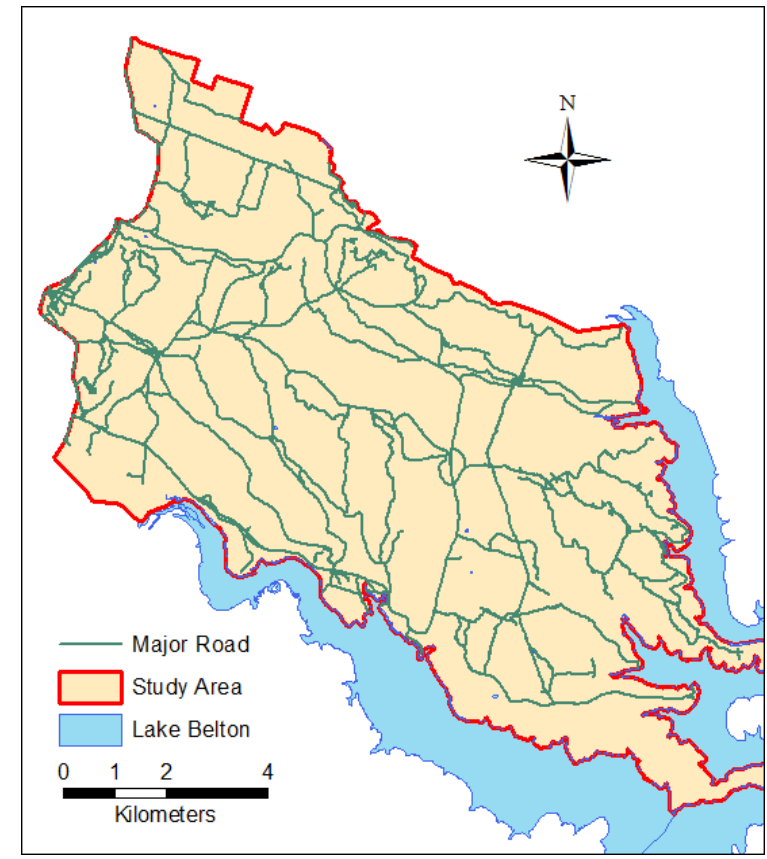

Figure 7. All major roads within the study area were digitized to facilitate classification of depressions that were influenced by roads and infrastructure. All depressions within $20 \mathrm{~m}$ of the major roads were removed from the depression database.

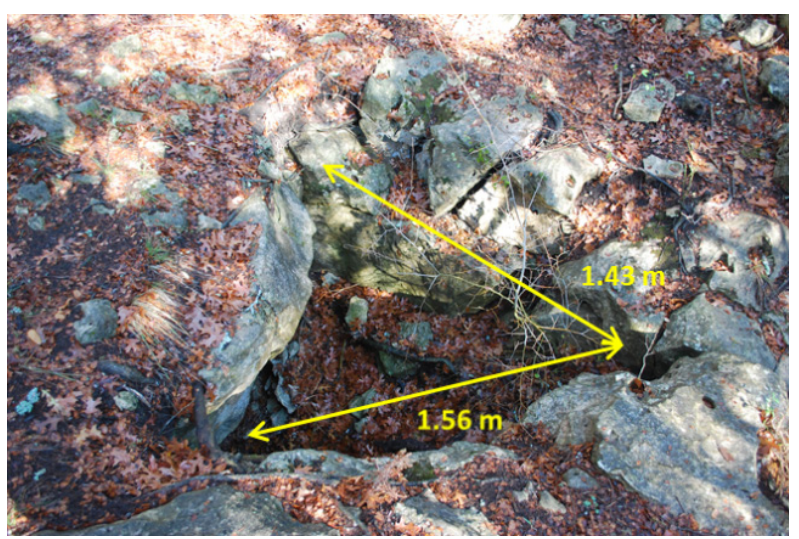

Figure 8. Typical small depression found within the study area, with major and minor axes measuring 7.56 $\mathrm{m}$ and $1.43 \mathrm{~m}$ respectively, and a depth of $.67 \mathrm{~m}$. 
After all classifications had been made and the depression database had been filtered by potential interference with natural processes and artificial structures, a total of 1,538 depressions remained in the database. A significant number of features intersected or overlapped with more than one classification type, with the most common parameter associations found between streams and roads, and secondly, between streams or roads and geology (Table 2).

\section{Depression Density}

Depression density maps were created to show the spatial distribution of delineated depressions before and after filtering across the study area. Point maps were generated to show the centroid point of each depression identified, and density values were found by using the centroid point of each depression object which depicts the number of depressions found within

Table 1. The table below categorizes the number of depressions that were removed by the filtering mechanisms used in the study. Many of the depressions were filtered by more than one mechanism; therefore the total number of sinks delineated and removed is greater than the total number of sinks in the database.

\begin{tabular}{|c|c|c|}
\hline $\begin{array}{c}\text { Type of } \\
\text { Classification } \\
\text { Interference }\end{array}$ & $\begin{array}{c}\text { Filtering } \\
\text { Mechanism }\end{array}$ & $\begin{array}{c}\text { Number of } \\
\text { Sinks } \\
\text { Removed }\end{array}$ \\
\hline Water Bodies & $20 \mathrm{~m}$ & 31 \\
\hline Vegetation & cover type & 692 \\
\hline Roads & $20 \mathrm{~m}$ & 905 \\
\hline Geology & lithology & 1,628 \\
\hline Streams & $5 \mathrm{~m}$ & 4,028 \\
\hline Depth & $<0.275 \mathrm{~m}$ & 4,091 \\
\hline
\end{tabular}

Table 2. The number of classification interferences and the percent of the total depressions that were removed as a result of these filtering processes.

\begin{tabular}{|c|c|c|}
\hline $\begin{array}{c}\text { Number of } \\
\text { Classification } \\
\text { Interferences }\end{array}$ & $\begin{array}{c}\text { Number } \\
\text { of } \\
\text { Depressions }\end{array}$ & $\begin{array}{c}\text { Percent of } \\
\text { Total } \\
\text { Depressions }\end{array}$ \\
\hline 0 & 1,538 & $16.763 \%$ \\
\hline 1 & 4,659 & $50.779 \%$ \\
\hline 2 & 2,301 & $25.079 \%$ \\
\hline 3 & 589 & $6.420 \%$ \\
\hline 4 & 87 & $0.948 \%$ \\
\hline 5 & 1 & $0.011 \%$ \\
\hline 6 & 0 & $0.000 \%$ \\
\hline Total & 9,175 & $100 \%$ \\
\hline
\end{tabular}

a one square kilometer search radius. The density map of all delineated depressions shows that high-density regions are concentrated near major roads, large stream segments, areas of lower elevation, and within training areas currently used by the military (Figure 9).

The density map of depressions that did not intersect or overlap with any of the classification determinants shows that the densest areas are limited to topographically high regions of the study area (Figure 10), particularly those associated with high plateaus and steeper scarps; however some appear to be associated with anthropogenic structures and modifications not previously filtered.

\section{Slope Analysis}

Slope analysis of the study area was performed through the creation and classification of a raster image representing the slope per cell (Figure 11). Shelter caves previously mapped by Reddell et al. (2011) were plotted on the slope analysis map. These shelter caves may represent discharge features with limited connectivity to depressions at the surface. The slopes that were determined to be related to areas of known shelter cave

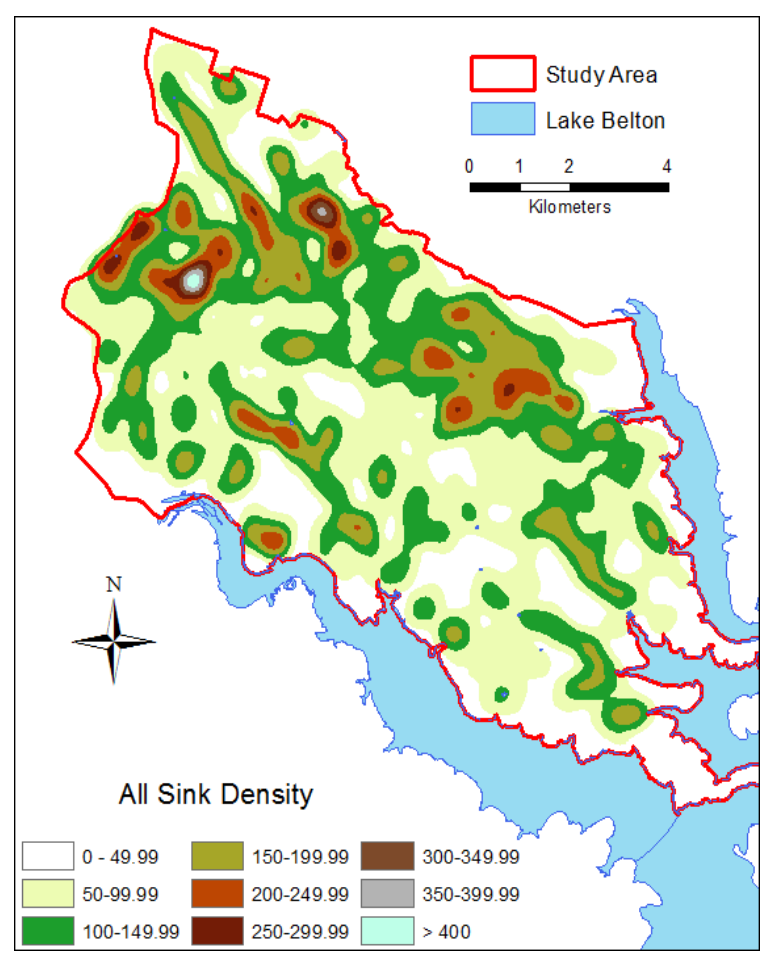

Figure 9. After the initial analysis, 9,175 depressions were identified. A kernel density map was generated with the highest concentration of depressions associated with major roads, streams, and training areas. 


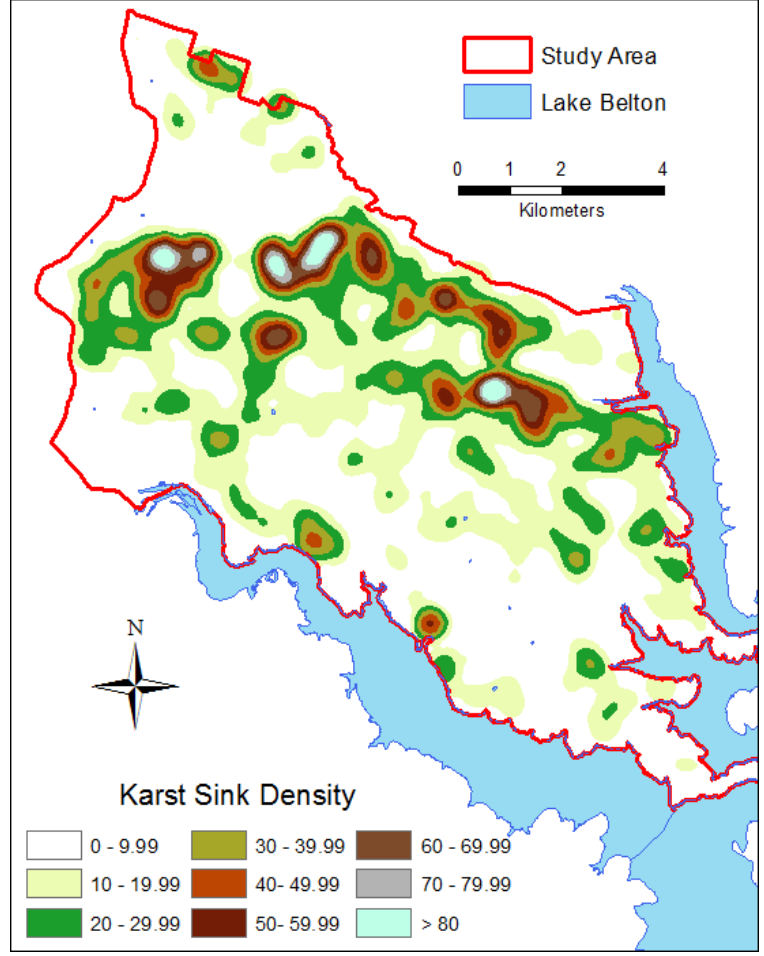

Figure 10. After classification and removal of the identified depressions, 1,538 remained in the database. A kernel density map for these remaining depressions was generated, showing the greatest accumulation in the northern part of the study area and along the shores of Lake Belton.

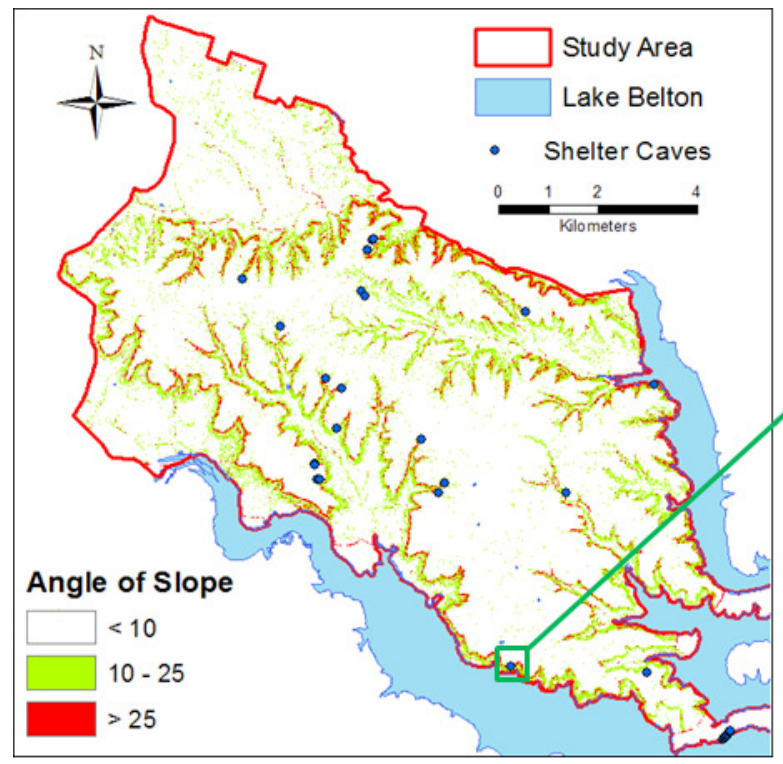

development are greater than 25 degrees from horizontal. The slopes found to be greater than 25 degrees are mainly limited to areas of scarp development, with most occurring along the dissected edges of stream segments across the northern part of the study area and along the shores of Lake Belton.

\section{Conclusions}

This study utilized LiDAR data to resolve depression features in the Owl Mountain province on the Fort Hood Military Reservation with an elevation model at a resolution of $1 \mathrm{~m}$. Due to the limitations of the data, any depression features smaller than $1 \mathrm{~m}^{2}$ could not be resolved. While the majority of natural depression features related to karsting in the study area do not have depths greater than $1 \mathrm{~m}$, any depression features whose depth was less than the vertical accuracy of the LiDAR survey were omitted because they could not be accurately interpreted. In addition, the study area has been extensively modified by past and current military use, thus depressions and other surface scars related to military use cover most of the study area and must be taken into consideration when interpreting results. The combination of heavy military use and high resolution elevation data make it extremely difficult to discern between whether identified depressions are natural or artifacts; therefore, models developed from LiDAR analyses at Fort Hood are assumed to have errors, both

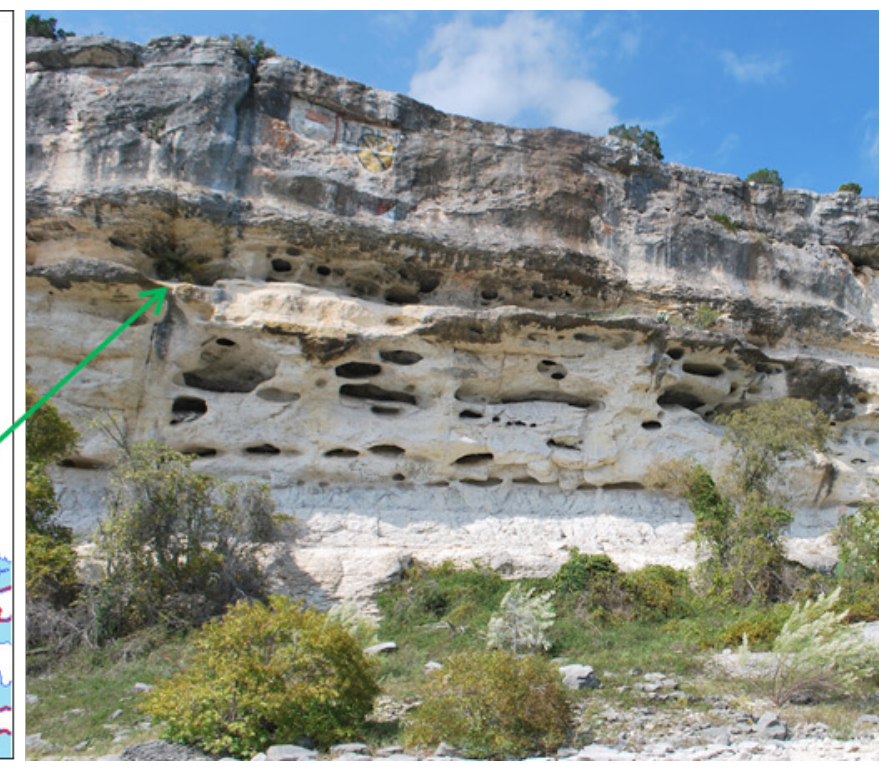

Figure 11. Left: Slope analysis of the Owl Mountain province with shelter caves identified in study area. Right: Scarp development is greatest along the shores of Lake Belton; the interfingering nature of the Comanche Peak and Edwards Formation provides horizontal flow paths for surface waters and enhances shelter cave development. 
in the inclusion of anthropogenic depressions and the exclusion of natural depressions.

Although LiDAR analyses can be a powerful tool, filter mechanisms must be employed to remove major natural and anthropogenic terrain modifications resulting from military use, road building and maintenance, and the natural influence of water bodies throughout the study area. The results of LiDAR analyses are directly related to the quality and density of the initial LiDAR survey, with accuracy and quality limited by time and monetary constraints. Because the resolution of the LiDAR survey determines the scale of ground features that can be resolved, limitations will exist based on the accuracy of the collected data.

\section{References}

Adkins WS, Arick MB. 1930. Geology of Bell County, Texas. The University of Texas Bulletin No. 3016, Austin (TX): Bureau of Economic Geology.

Amsbury DL, Bay Jr TA, Lozo FE. 1984. A Field Guide to Lower Cretaceous Carbonate Strata in the Moffatt Mound Area near Lake Belton, Bell County, Texas. Guidebook for SEPM Field Trip NO. 3. San Antonio, Texas: Gulf Coast Section of the Society of Economic Paleontologists and Mineralogists Foundation.

Barnes V. 1970. Geologic Atlas of Texas: Waco Sheet. Map and Lithology description, Austin (TX): Bureau of Economic Geology.

Bradley RG, Malstaff G. 2004. Dry Periods and Drought Events of the Edwards Plateau, Texas. Austin (TX): Texas Water Development Board.

Brown JL. 1975. Paleoenvironment and Diagenetic History of the Moffat Mound, Edwards Formation, Central Texas. [Master's Thesis]. Baton Rouge (LA) Louisiana State University.

Bryant AW. 2012. Geologic and Hydrogeologic Characterization of Groundwater Resources in the Fredericksburg Group, North Nolan Creek Province, Bell County, Texas. [Master's Thesis]. Nacogdoches (TX): Stephen F. Austin State University. 223 p.

Elliott WR, and Veni G, editors. 1994. The Caves and Karst of Texas. Huntsville, AL: National Speleological Society and Texas Parks and Wildlife Department.

Esri 2012, ArcGIS Desktop 10 Resource Center. Available from: http://help.arcgis.com/en/arcgisdesktop/10.0/ help/index.html\# (accessed October 2012).

Fisher WL, Rodda PU. 1969. Edwards Formation (Lower Cretaceous), Texas: Dolomitization in a Carbonate Platform System. American Association of Petroleum Geologists 53, (1): 55-72.
Flood M, 2004. ASPRS Guidelines Vertical Accuracy Reporting for LiDAR Data, ASPRS, p. 1-20.

Liu X. 2008. Airborne LiDAR for DEM Generation: Some Critical Issues, Progress. Physical Geography 32 (1): 1-49.

Liu H, Wang L. 2008. Mapping Detention Basins and Deriving Their Spatial Attributes from Airborne LiDAR Data for Hydrological Applications. Hydrological Processes 22 (1): 2358-2369.

McCann AJ. 2012. Surficial Fractures and Their Interferences on Fluid Movement in Hydrogeologic Reservoirs, Central Texas, [Masters Thesis]. Nacogdoches (TX): Stephen F. Austin State University. 234 p.

Nelson HF. 1973. The Edwards Reef Complex and Associated Sedimentation. The Geological Society of America. Dallas (TX): Bureau of Economic Geology, p 1-35.

Optimal Geomatics. 2009. Ft. Hood, Texas Flight Report: LiDAR Data Acquisition Flown in March 2009 in support of: Topographic LiDAR Data Services, Optimal Geomatics Inc., p. 3.

Optimal Geomatics. 2009. LiDAR Data Processing Procedures Report, Optimal Geomatics Inc., p. 5.

Picinich C. 2011. Land Group 3 and Land Group 4 Vegetation Sampling on Fort Hood, Texas in Endangered species monitoring and management at Fort Hood, Texas. Fort Hood (TX): Fort Hood Directorate of Public Works, Natural Resources Management Branch.

Reddell JR, Fant J, Reyes M, Warton M. 2011. Karst Research on Fort Hood, Bell and Coryell Counties, Texas. Unpublished Report, Fort Hood (TX): Fort Hood Natural Resources Management Branch.

Senger RK, Collins EW, Kreitler CW. 1990. Hydrogeology of the Northern Segment of the Edwards Aquifer, Austin Region. Report of Investigations No. 192, Austin (TX): Bureau of Economic Geology.

Stafford, KW, Rosales-Lagarde L, Boston PJ, 2002, Castile Evaporite Karst Potential Map of the Gypsum Plain, Eddy County, New Mexico and Culberson County, Texas: A GIS Methodological Comparison. Journal of Cave and Karst Studies 70 (1): 35-46.

Wang L, Liu H. 2005. An Efficient Method for Identifying and Filling Surface Depressions in Digital Elevation Models for Hydrologic Analysis and Modeling. International Journal of Geographical Information Science. 1-20. 
468 NCKRI SYMPOSIUM 2 13TH SINKHOLE CONFERENCE 